Irwan Ritonga ${ }^{1}$

Nevi Yarni ${ }^{2}$

\section{HUBUNGAN KESEGARAN JASMANI DAN MOTIVASI BELAJAR DENGAN HASIL BELAJAR SISWA KELAS V SDN 12 PULAU PUNJUNG}

\begin{abstract}
Abstrak
Latar belakang penelitian ini adalah rendahnya hasil belajar siswa, sebagian siswa kurang menyenangi kegiatan olahraga, siswa tidak bersemangat melakukan aktivitas olahraga, siswa kurang percaya diri dalam melakukan aktivitas olahraga, kesehatan fisik siwa yang kurang mendukung. Tujuan yang ingin dicapai dalam penelitian ini adalah 1) hubungan kesegaran jasmani terhadap hasil belajar siswa kelas V SDN 12 Pulau Punjung, 2) hubungan motivasi belajar terhadap hasil belajar siswa kelas V SDN 12 Pulau Punjung, 3) Hubungan secara bersama-sama kesegaran jasmani dan motivasi belajar terhadap hasil belajar siswa kelas $\mathrm{V}$ SDN 12 Pulau Punjung. Jenis penelitian ini adalah deskriptif korelasional. Populasi dalam penelitian ini berjumlah 149 orang, pengambilan sampel menggunakan teknik proportional random sampling didapatkan sampel 25 orang Siswa Putra. Teknik analisa data menggunakan rumus korelasi product moment. Hasil penelitian ini menggambarkan bahwa kesegaran jasmani berhubungan dengan hasil belajar siswa Putra SDN 12 Pulau Punjung rhitung $>$ rtabel 0,654>0,396, motivasi belajar siswa berhubungan dengan hasil belajar siswa putra rhitung>rtabel 0,453>0,396. Kesegaran jasmani berhubungan dengan hasil belajar siswa Putra SDN 12 Pulau Punjung rhitung $>$ rtabel 0,488>0,413, motivasi belajar berhubungan dengan hasil belajar siswa putri rhitung>rtabel 0,420>0,413. Kesegaran jasmani dan motivasi belajar siswa bersama-sama berhubungan dengan hasil belajar siswa putra sebesar 51,5\%. Kesegaran jasmani dan motivasi belajar bersama-sama berhubungan dengan hasil belajar siswa putri sebesar 76,9\%.
\end{abstract}

Keywords: Kesegaran Jasmani, Motivasi Belajar, Hasil Belajar

\begin{abstract}
The background of this study is the low student learning outcomes, some students do not like sports activities, students are not eager to do sports activities, students lack confidence in sports activities, physical health of students who are less supportive. The objectives to be achieved in this study are 1) the relationship of physical fitness to the learning outcomes of fifth grade students at SDN 12 Pulau Punjung, 2) the relationship of learning motivation towards the learning outcomes of fifth grade students at SDN 12 Pulau Punjung, 3) Relationships together with physical fitness and learning motivation towards student learning outcomes of grade V SDN 12 Pulau Punjung. This type of research is descriptive correlational. The population in this study amounted to 149 people, sampling using proportional random sampling techniques obtained a sample of 25 male students. Data analysis techniques using the product moment correlation formula. The results of this study illustrate that physical fitness is related to the learning outcomes of male students at SDN 12 Pulau Punjung rhitung> rtabel 0.654>0.396, student motivation to learn is related to learning outcomes of male students rcount> rtable 0.453>0.396. Physical fitness relates to the learning outcomes of male students of SDN 12 Pulau Punjung rcount> rtable 0.488> 0.413, learning motivation is related to the learning outcomes of female students rcount> rtable 0.420>0.413. Physical fitness and student motivation together associated with male student learning outcomes by $51.5 \%$. Physical fitness and learning motivation together are related to the learning outcomes of female students by $76.9 \%$.
\end{abstract}

Keywords: Physical Freshness, Learning Motivation, Learning Outcomes

\footnotetext{
${ }^{1}$ Mahasiswa Prodi Ilmu Pendidikan, Universitas Negeri Padang Alamat email irwanritongga@gmail.com

${ }^{2}$ Dosen/Staf pengajar Prodi Ilmu Pendidikan, Universitas Negeri Padang
} 


\section{PENDAHULUAN}

Pada dasarnya pendidikan jasmani ialah suatu bagian dari pendidikan secara keseluruhan yang mengutamakan aktivitas jasmani dan pembinaan hidup sehat untuk pertumbuhan dan pengembangan jasmani, mental, sosial, serta emosional yang serasi, selaras dan seimbang. Hasil yang diharapkan dari pendidikan jasmani adalah selain penguasaan berbagai keterampilan gerak dasar juga kondisi fisik atau derajat sehat yang baik, sehingga dihasilkan tingkat kebugaran jasmani yang prima.

Fungsi pendidikan jasmani menurut Purnomo (Buletin Kesjas Edisi 2/th II/1995:8), yaitu: (1) meningkatkan pertumbuhan dan perkembangan tubuh yang meliputi kebugaran jasmani dan kesehatan, (2) meningkatkan ketangkasan dan keterampilan, (3) meningkatkan pengetahuan dan kecerdasan, (4) menambah kehidupan sosial yang kreatif dan rekreatif. Tingkat kebugaran jasmani yang prima ini akan membantu memudahkan bagi siswa dalam mempelajari semua mata pelajaran yang ada di bangku sekolah.

Dukungan kebugaran jasmani sangat diperlukan oleh para siswa sekolah untuk dapat mengikuti proses pembelajaran setiap hari yang rata-rata membutuhkan waktu lima jam. Dengan demikian tidak diragukan lagi bahwa pendidikan jasmani memang sangat dibutuhkan oleh para siswa sekolah untuk meningkatkan dan menjaga kebugaran jasmani. Menurut Wiranto (1997:3), kecerdasan dan kreatifitas yang diperoleh melalui olahraga hendaknya melekat pada kepribadian dan kemampuan seseorang. Peningkatan kebugaran jasmani diharapkan dapat ditransfer secara positif ke dalam kemampuan belajar kognitif. Hal ini diharapkan tercermin dari meningkatnya hasil prestasi belajar siswa dalam proses pembelajaran matematika, ilmu pengetahuan alam (MIPA) dan ilmu pengetahuan sosial (IPS), yang perlu dibuktikan dalam penelitian ini (Zagoto, dkk., 2018; Sarumaha, 2018 ; Dakhi, O., 2013).

Melalui Pendidikan Jasmani dan olahraga, diharapkan para siswa dapat lebih mudah menguasai konsepkonsep dan keterampilan yang lainnya, sehingga terjadi transfer hasil belajar pendidikan jasmani yang positif terhadap penguasaan konsep-konsep dan keterampilan bidang studi lainnya. Pendidikan jasmani dengan pengayaan program kurikuler diharapkan akan sangat bermakna dalam peningkatan kebugaran jasmani guna mendukung pencapaian prestasi belajar pada umumnya.

Fenomena di temui SDN 12 Pulau Punjung terlihat hasil belajar siswa masih rendah, hal ini terlihat masih banyak siswa yang belum tuntas dalam pembelajaran Penjasorkes, faktor yang mempengaruhinya antara lain faktor internal, eksternal dan faktor pendekatan, terlihat lebih dari separoh sekitar $60 \%$ siswa yang belum tuntas pada saat melaksanakan ujian mid sementer, disisi lain terlihat banyak siswa yang kurang menyukai aktivitas olahraga, mereka mengemukakan berbagai alasan salah satunya kondisi fisik tidak kuat untuk melakukan olah raga, tetapi ada sebagian siswa yang kurang percaya diri dalam melakun aktivitas olahraga sehingga timbul rasa minder, rasa takut, keluar keringan untuk mengikuti olahraga dan kurangnya motivasi siswa dalam mengikuti kegiatan olahraga yang berimbas rendahnya hasil belajar siswa, kemauan siswa dalam melakukan aktivitas olahraga relihat masih rendah. Motivasi merupakan suatu hal pengerak yang mendorong seseorang melakukan kegiatan olahraga, dengan dorongan dari dalam diri membuat siswa akan lebih bersemangat melakukan kegiatan olahraga, jika seseorang mempunyai kesegaran jasmani yang baik dan motivasi yang tinggi maka akan meningkatkan hasil belajar.

Berdasarkan hal di atas maka penulis tertarik menuangkan dalam sebuah skripsi yang akan dilihat faktor-faktor yang mempengaruhi rendahnya hasil belajar siswa.

\section{METODOLOGI PENELITIAN}

\section{Jenis Penelitian}

Jenis penelitian ini dapat digolongkan ke dalam penelitian deskriptif korelasional yang bertujuan untuk mengetahui ada tidaknya hubungan kesegaran jasmani dengan hasil belajar siswa XI SDN 12 Pulau Punjung. Pendapat Arikunto (2010:186) bahwa "Penelitian korelasi bertujuan untuk menemukan ada tidaknya hubungan dan apabila ada, berapa eratnya hubungan serta berarti atau tidaknya hubungan itu".

\section{Populasi Penelitian}

Populasi adalah seluruh penduduk yang diselidiki dan bergai oleh sejumlah individu yang paling sedikit memiliki sifat yang sama (Sutrisno Hadi, 2004:77). Populasi dalam penelitian ini adalah seluruh siswa kelas XI SDN 12 Pulau Punjung yang berjumlah sebanyak 149 orang. Untuk lebih jelasnya dapat dilihat pada berikut ini:

\section{Sampel}

Sampel adalah sebagian dari wakil yang diteliti (Suharsimi Arikunto, 2002:109), sedangkan besar kecilnya sampel dari jumlah populasi sebenarnya tidak ada ketentuan yang mutlak, berapa persen sampel yang diambil dari populasi (Sutrisno Hadi, 2004:81) 
Sampel dalam penelitian ini adalah siswa kelas XI ditentukan dengan rumus Slovin yang dikutip (Umar 2004:62 ) sebagai berikut:

$$
n=\frac{N}{N \cdot d^{2}+1}
$$

Di mana :

$$
\begin{array}{ll}
\mathrm{n} & =\text { Besar sampel } \\
\mathrm{N} & =\text { Besar populasi }
\end{array}
$$

$\mathrm{e} \quad=$ Nilai kritis/batas ketelitian yang diinginkan (persentase kelonggaran penelitian pengambilan sampel dalam penelitian adalah $10 \%$ Dalam penelitian ini $\mathrm{N}=149$ dengan $\mathrm{e}=10 \%$

berdasarkan rumus di atas maka jumlah sampel penelitian ini adalah

$$
n=\frac{149}{149 .(10 \%)^{2}+1}=48,1
$$

dibulatkan menjadi 48 orang. Pengambilan sampel menggunakan teknik proportional random sampling. Namun dalam penelitian ini yang diambil siswa putra sebanyak 25 orang.

\section{Instrumen Penelitian}

Instrumen mencakup segala sesuatu yang digunakan sebagai alat dalam penelitian ini adalah Tes (kesegaran jasmani)

Tes adalah serentetan pernyataan atau laithan serta alat lain yang digunakan untuk mengukur keterampilan, pengetahuan, intelensi, kemampuan dan tingkat kesegaran jasmani dengan melalui tes uji keterampilan dengan penduan menurut sistem (TKJI) Tes Kesegaran Jasmani Indonesia, pusat kesegaran jasmani dan rekreasi. Bentuk tesnya adalah 1) lari cepat, 2) gantung siku teguk, 3) Baring duduk, 4) loncat tegak, 5) lari jarak menengah. Putra berjumlah 25 orang dan putri berjumlah 23 orang. Norma-norma tes dapat

\begin{tabular}{|c|c|c|c|c|c|c|c|c|c|}
\hline \multirow{2}{*}{\multicolumn{2}{|c|}{ Butir Tes }} & \multicolumn{2}{|c|}{6 s.d 9 th } & \multicolumn{2}{|c|}{10 s.d 12 th } & \multicolumn{2}{|c|}{13 s.d 15 th } & \multicolumn{2}{|c|}{16 s.d 19 th } \\
\hline & & Putri & Putra & Putri & Putra & Putri & Putra & Putri & Putra \\
\hline 1 & $\begin{array}{l}\text { Lari cepat } \\
\text { (sprint) }\end{array}$ & $30 \mathrm{~m}$ & $30 \mathrm{~m}$ & $40 \mathrm{~m}$ & $40 \mathrm{~m}$ & $50 \mathrm{~m}$ & $50 \mathrm{~m}$ & $60 \mathrm{~m}$ & $60 \mathrm{~m}$ \\
\hline $2^{a}$ & $\begin{array}{l}\text { Gantung Siku } \\
\text { Tekuk }\end{array}$ & $\sqrt{ }$ & $\sqrt{ }$ & $\sqrt{ }$ & $\sqrt{ }$ & $\sqrt{ }$ & - & $\sqrt{ }$ & - \\
\hline $2^{b}$ & $\begin{array}{l}\text { Gantung } \\
\text { Angkat } \\
\text { Tubuh }\end{array}$ & - & - & - & - & - & $\sqrt{ }$ & - & $\sqrt{ }$ \\
\hline 3 & Baring Duduk & $30 "$ & $30 "$ & $30 "$ & $30 "$ & $60 "$ & $60 "$ & $60 "$ & $60 "$ \\
\hline 4 & Loncat Tegak & $\sqrt{ }$ & $\sqrt{ }$ & $\sqrt{ }$ & $\sqrt{ }$ & $\sqrt{ }$ & $\sqrt{ }$ & $\sqrt{ }$ & $\sqrt{ }$ \\
\hline 5 & $\begin{array}{l}\text { Lari Jarak } \\
\text { Menengah }\end{array}$ & $600 \mathrm{~m}$ & $600 \mathrm{~m}$ & $600 \mathrm{~m}$ & $600 \mathrm{~m}$ & $\begin{array}{c}800 \\
m\end{array}$ & $1000 \mathrm{~m}$ & $1000 \mathrm{~m}$ & $1200 \mathrm{~m}$ \\
\hline
\end{tabular}
dilihat pada tabel dibawah ini

Tabel 1. Norma-norma Tes dalam Rangkaian TKJI Berdasarkan Kelompok Usia dan Jenis Kelamin

Metode angket (motivasi belajar)

Dalam penelitian ini, peneliti menggunakan metode angket langsung dengan bentuk tertutup menggunakan skala likert, responden memilih alternatif jawaban yang telah disediakan dengan pendapatnya. 
Ada lima alternatif yang masing-masing mempunyai skor adalah sebagai berikut: selalu (SL), Sering (SR), Kadang-Kadang (KD), Jarang (JR), Tidak Pernah (TP).

Tabel 2 Kisi-kisi Instrumen

\begin{tabular}{|c|c|c|}
\hline Variabel & Indikator & Item \\
\hline \multicolumn{3}{|c|}{ Kesegaran Jasmani (X1) } \\
\hline \multirow{5}{*}{$\begin{array}{c}\text { Motivasi Belajar } \\
\text { (X2) }\end{array}$} & Adanya semangat yang tinggi dalam belajar & 10 \\
\hline & Tekun dalam belajar & 10 \\
\hline & $\begin{array}{l}\text { Perasaan senang dalam mengerjakan tugas-tugas } \\
\text { pembelajaran }\end{array}$ & 7 \\
\hline & $\begin{array}{l}\text { Tidak cepat putus asa menghadapi tugas-tugas yang } \\
\text { sulit }\end{array}$ & 6 \\
\hline & Keinginan untuk sukses & 7 \\
\hline Hasil Belajar (Y) & & \\
\hline
\end{tabular}

\section{Dokumentasi (hasil Belajar)}

Suharsimi (2002:206) metode dokumentasi yaitu cara mencari data melalui catatan, transkrip, buku, surat kabar, majalah, prasasti, notulen rapat, lengger, agend dan sabaginya. Dalam hal ini pengambilan data mengenai hasil belajar penjas diambil dari rata-rata nilai semester satu.

\section{Teknik Pengumpulan Data}

Teknik pengumpulan data yang digunakan dalam penelitian ini berupa angket tertutup, yang telah disusun sesuai dengan variabel penelitian yang akan diberikan kepada responden. agar pengumpulan data dapat berlangsung secara teratur, sistematis dan sukses, maka peneliti melakukan hal-hal sebagai berikut:

1. Menyiapkan instrumen penelitian secara lengkap

2. Menetapkan sumber data

3. Menyiapkan operator pelaksana

4. Melakukan pengumpulan data secara sistematis sesuai dengan apa yang telah direncanakan sebelumnya

\section{Teknik Analisis Data}

Bagian ini menyebutkan dan menjelaskan teknik analisis yang digunakan untuk mengolah data yang telah dikumpulkan menjadi informasi bermakna. Metode analisis statistik yang digunakan dalam penelitian ini adalah multi korelasi dengan menggunakan tes analisis korelasi, kerana untuk menganalisis hubungan lebih dari 2 variabel tes. Penganalisasiannya dengan menggunakan korelasi yaitu dengan istilah statistik yang menyatakan derajat hubungan garis linear antara variabel dari penelitian yang terdiri dari dua variabel bebas dan satu variabel terikat maka penganalisisan data menggunakan analisis regresi ganda.

\section{Deskripsi Data}

Data ketiga variable , disajikan dalam bentuk distribusi frekuensi. Berdasarkan data frekuensi tersebut didapatkan skor mean, (nilai rata) modus (nilai yang sering muncul), median ( nilai tengah), dan standar deviasi. Untuk mengetahui tingkat pencapaian responden pada setiap variable digunakan rumus:

$$
\mathrm{DP}=\frac{\Sigma X}{n x \Sigma_{1} \text { xskalateringg }} \times 100 \%
$$

$$
\begin{aligned}
& \text { Keterangan: } \\
& \mathrm{DP}=\text { Derajat/ tingkat pencapaian } \\
& \Sigma x=\text { Skor rata-rata } \\
& N x \Sigma_{i} \quad=\text { Jumlah item instrument }
\end{aligned}
$$

Skala tertinggi $=5$

Untuk menentukan kategori tingkat pencapaian responden digunakan klasifikasi yang dikemungkakan Sudjana (1982:206), seperti berikut ini: 


\begin{tabular}{|c|l|}
\hline Persentase & \multicolumn{1}{|c|}{ Interpretasi } \\
\hline $90 \%-100 \%$ & Sangat Baik/ Sangat tinggi \\
\hline $80 \%-89 \%$ & Baik / Tinggi \\
\hline $65 \%-79 \%$ & Cukup/ Sedang \\
\hline $55 \%-64 \%$ & Kurang Baik/Kurang \\
\hline $0 \%-54 \%$ & Tidak Baik/ Rendah \\
\hline
\end{tabular}

1. Uji Persyaratan

Sebelum analisis data dilakukan, terlebih dahulu dilakukan pemeriksaan terhadap persyaratan analisis, Sudjana (1982) mengemuka-kan persyaratan tersebut sebagai berikut:

a) Pemeriksaan Normalitas data

Uji normalitas bertujuan untuk mengetahui normalitas sebaran ketiga variable penelitian. Untuk itu uji normalitas dilakukan dengan menggunakan uji kolmogorov-smirnov test (pengujian K-S)

b) Pemeriksaan Homogenitas populasi

Pemeriksaan homogenitas populasi dilakukan dengan menggunakan tekinik levene statistic Test ( uji LS), untuk melihat apakah data yang diperoleh berasal dari varinsi kelompok yang homogeny atau tidak.

c) Pemeriksaan Linearitas garis regresi

Pemeriksaan linearitas garis regresi dilakukan dengan teknik regresi sederhana. Pemerikasaan ini bertujuan untuk menentukan kelinearan hubungan antara variabel bebas dengan variabel terikat.

d) Pemeriksaan independensi variabel bebas

Pemeriksaan independent antar variabel bebas dilakukan dengan menggunakan rumus korelasi Product moment. Pemeriksaan ini bertujuan apakah data kedua variabel bebas tidak mempunyai hubungan yang berarti.

2. Uji Hipotesis

Pengujian hipotesis dengan menggunakan teknik korelasi dan regresi sederhana dan regrasi berganda dibantu dengan program SPSS versi 16.00

a. Hipotesis pertama dan kedua di uji dengan menggunakan teknik korelasi dan regresi sederhana. Besarnya koefisien korelasi $\mathrm{r}$ dihitung dengan menggunakan rumus product moment regresi sederhana untuk kesegaran jasmani dan motivasi belajar terhadap hasil belajar yang dihitung dengan model persamaan $\mathrm{Y}=\mathrm{a}+\mathrm{bx}$

b. Hipotesis ketiga diuji dengan menggunakan teknik korelasi dan regresi berganda. Koefisien korelasi berganda $(\mathrm{R})$ digunakan untuk mengetahui hubungan dan kontribusi dari kedua variabel secara bersama-sama terhadap hasil belajar. Analisis regresi ganda digunakan untuk memprediksi bagaimana pengaruh variabel terikat bila variabel bebas sebagai faktor prediktor. Persamaan regresi ganda untuk dua prediktor adalah $\mathrm{Y}=\mathrm{a}+\mathrm{b} 1 \mathrm{X} 1+\mathrm{b} 2 \mathrm{X}_{2}$

\section{HASIL DAN PEMBAHASAN}

Pada bagian ini dipaparkan dan dibahas data penelitian yang meliputi : a) deskripsi data, b) pengujian persyaratan analisis meliputi data bersumber dari sampel yang dipilih secara acak,uji normalitas data, pengujian independensi antar variabel bebas dan uji linieritas, c) pengujian hipotesis, d) pembahasan Berikut ini dipaparkan satu persatu.

Data penelitian ini terdiri dari tiga variabel yaitu data variabel hasil belajar siswa, variabel kesegaran jasmani, variabel kesegaran jasmani siswa,. Data tersebut dideskripsikan sebagai berikut:

\section{Hasil Belajar Siswa Putra SDN 12 Pulau Punjung}

Hasil belajar siswa Putra SDN 12 Pulau Punjung minimum 0 dan skor maksimum 100. Dari jawaban responden, diperoleh skor terendah 60 dan skor tertinggi 85. Hasil pengolahan data diperoleh skor rata-rata (mean) sebesar 71,16, modus (mode) sebesar 75,0 median sebesar 73,0 dan simpangan baku (standar deviation) sebesar 6,3. Harga skor rata-rata, modus dan median tidak jauh berbeda dan tidak melebihi satu simpangan baku, ini berarti bahwa distribusi hasil belajar siswa cenderung normal. 


\section{Kesegaran jasmani Siswa Putra SDN 12 Pulau Punjung}

Berdasarkan hasil pengolahan data diperoleh skor rata-rata (mean) sebesar 10,9, modus (mode) sebesar 8,0, median sebesar 11,0 dan simpangan baku (standar deviation) sebesar 2,2. Harga skor rata-rata, modus dan median tidak jauh berbeda dan tidak melebihi satu simpangan baku, ini berarti bahwa distribusi skor kesegaran jasmani siswa cenderung normal.

\section{Motivasi belajar siswa Putra SDN 12 Pulau Punjung}

Angket variabel motivasi belajar siswa terdiri dari 35 butir. Maka skor minimum 35 dan skor maksimum 175. Dari jawaban responden, diperoleh skor terendah 100 dan skor tertinggi 158. Hasil pengolahan data diperoleh skor rata-rata (mean) sebesar 128,9, modus (mode) sebesar 117,0, median sebesar 132,0 dan simpangan baku (standar deviation) sebesar 15,71. harga skor rata-rata, modus dan median tidak jauh berbeda dan tidak melebihi satu simpangan baku, ini berarti bahwa distribusi motivasi belajar siswa cenderung normal. Gambaran distribusi frekuensi skor motivasi belajar siswa, dapat dilihat pada Tabel 8 dan grafik histogramnya pada Gambar 3

\section{Pengujian Persyaratan Analisis}

Uji persyaratan analisis dilakukan dengan menggunakan bantuan program SPSS Versi 16.00. Rincian masing-masing uji persyaratan analisis yang dimaksudkan diuraikan sebagai berikut :

\section{Uji Normalitas Data}

Pengujian normalitas data dilakukan dengan menggunakan tes Kolmogrof Smirnov (Tes K-S), dengan menetapkan taraf signifikasn 5\% atau $\alpha=0,05$ (Sudjana, 1982:280). Data dapat dikatakan berdistribusi normal jika taraf signifikan (Asymp.Sig) 0,05. Hasil analisis dapat dilihat pada Lampiran dan Tabel 11 di bawah ini:

Tabel 3. Hasil Uji Normalitas Variabal $\mathrm{X}_{1}, \mathrm{X}_{2}$ dan $\mathrm{Y}$ dengan tes Kolmogrov Smirnov (Putra)

\begin{tabular}{|l|c|c|c|c|}
\hline \multicolumn{1}{|c|}{ Variabel } & KS & Asymp Sig & Pengujian & Keterangan \\
\hline Kesegaran jasmani $\left(\mathrm{X}_{1}\right)$ & 0,881 & 0,419 & 0,05 & Normal \\
\hline Motvasi belajar $\left(\mathrm{X}_{2}\right)$ & 0,853 & 0,853 & 0,05 & Normal \\
\hline Hasil Belajar $(\mathrm{Y})$ & 0,840 & 0,481 & 0,05 & Normal \\
\hline
\end{tabular}

\section{Pengujian Hipotesis}

Hipotesis yang diajukan dalam penelitian ini ada 3 hipotesis, pertama "Kesegaran jasmani Siswa putra berhubungan dengan hasil belajar siswa", kedua "motivasi belajar siswa putra berhubungan dengan hasil belajar siswa", ketiga "Kesegaran jasmani Siswa dan motivasi belajar secara bersama-sama berhubugan dengan hasil belajar siswa".

\section{Hipotesis Pertama}

Hipotesis pertama yang diuji dalam penelitian ini adalah kesegaran jasmani berhubungan dengan hasil belajar siswa. Untuk mengetahui hungan didasarkan pada angka koefisien determinasi. untuk menguji hipotesis ini terlebih dahulu dilakukan analisis korelasi sederhana. Pengujian hipotesis dilakukan dengan mengg-unakan hipotesis sebagai berikut

Hasil analisis korelasi kesegaran jasmani dengan hasil belajar siswa dapat dilihat pada rangkuman analisis

dapat dilihat

pada

Tabel

13. 
Tabel 4. Rangkuman Hasil Analisis Korelasi Kesegaran jasmani Siswa $\left(X_{1}\right)$ dengan Hasil Belajar Siswa (Y)

\begin{tabular}{|c|c|}
$\mathrm{R}$ & $\mathrm{R}$ Square \\
\hline $0.654^{\mathrm{a}}$ & 0.427
\end{tabular}

Hasil perhitungan pada Tabel 13 menunjukkan bahwa koefisien korelasi antara kesegaran jasmani dengan hasil belajar siswa putra adalah sebesar $\mathrm{r}$ hitung $=0,654$ dan $\mathrm{r}$ tabel 0,396 ( $\mathrm{r}$ hitung> 0,654 rtabel 0,396 ) Berdasarkan hasil perhitungan ini dapat dijelaskan bahwa kesegaran jasmani berkorelasi sangat signifikan dengan hasil belajar siswa, dan bentuk hubungannya positif dengan koefisien determinasi $=0,427$

Selanjutnya, untuk mengetahui bentuk hubungan kesegaran jasmani siswa putra $\left(\mathrm{X}_{1}\right)$ dengan hasil belajar (Y), apakah hubungan itu besifat prediktif atau tidak, maka dilakukan analisis regresi sederhana. Dari hasil analisis diperoleh persamaan regresi $\hat{\mathbf{Y}} \mathbf{5 8 , 6 8 7 + 1 , 1 3 8} \mathbf{X}_{\mathbf{1}}$. Selanjutnya dilakukan uji keberartian koefisien regresi. Rangkuman hasil analisis dapat dilihat pada Tabel 14

Berdasarkan hasil pengujian di atas yang semuanya signifikan maka hipotesis yang menyatakan bahwa Kesegaran jasmani berhubungan dengan Hasil belajar siswa dapat diterima dalam taraf kepercayaan 95\% dan besar hubungan $42,77 \%$.

\section{Hipotesis Kedua}

Hipotesis kedua yang diuji dalam penelitian ini adalah motivasi belajar siswa berhubungan dengan hasil belajar siswa. Untuk menguji hipotesis ini terlebih dahulu dilakukan analisis korelasi sederhana. Hasil analisis korelasi motivasi belajar siswa dengan hasil belajar siswa dapat dilihat pada rangkuman analisis dapat dilihat pada Tabel 5.

Tabel 5. Rangkuman Hasil Analisis Korelasi Variabel motivasi belajar siswa $\left(\mathbf{X}_{2}\right)$ dengan Variabel Hasil Belajar Siswa (Y)

\begin{tabular}{|c|c|c|}
\hline Korelasi & Koefisien Korelasi (r) & Koefisien Determinasi \\
\hline (ryl) & 0,453 & 0,453 \\
\hline
\end{tabular}

Hasil perhitungan pada Tabel 5 menunjukkan bahwa koefisien korelasi antara motivasi belajar dengan hasil belajar adalah sebesar rhitung $=0,453$ dengan $\mathrm{r}$ tabel 0,396 ( $\mathrm{r}$ hitung $>\mathrm{r}$ tabel) Berdasarkan hasil perhitungan ini dapat dijelaskan bahwa motivasi belajar berkorelasi sangat signifikan dengan hasil belajar siswa, dan bentuk hubungannya positif dengan koefisien determinasi $=0,205$

Selanjutnya, untuk mengetahui bentuk hubungan motivasi belajar siswa $\left(\mathrm{X}_{2}\right)$ dengan hasil belajar siswa (Y), apakah besifat prediktif atau tidak, maka dilakukan analisis regresi sederhana. Dari hasil analisis diperoleh persamaan regresi $\hat{\mathbf{Y}}=\mathbf{6 0 + 0 7 2 , + 0 , 0 8 6} \mathbf{X}_{2}$. Rangkuman hasil analisis dapat dilihat pada Tabel 6.

Tabel 6. Uji Keberartian Koefisien $X_{2}$ terhadap $Y$

\begin{tabular}{|c|c|c|}
\hline Sumber & Koefisien & Sig. \\
\hline Konstanta & 60.072 & 0.000 \\
\hline Motivasi & 0.086 & 0.004 \\
\hline
\end{tabular}

Pada tabel 6 terlinat bahwa koefisien regresi $=0,086$ sangat signifikan dan dapat digunakan untuk memprediksi hasil belajar siswa. Model regresi di atas menjelaskan bahwa setiap peningkatan motivasi belajar siswa 1 skala akan berhubungan dengan hasil belajar sebesar 0,086 skala, dan skala hasil belajar sudah ada sebesar 60,072.

Berdasarkan hasil pengujian di atas yang semuannya signifikan maka hipotesis yang menyatakan bahwa motivasi belajar siswa berhubungan dengan hasil belajar siswa dapat diterima dalam taraf kepercayaan 95\% dan besar dampak

$=$ $20,5 \%$ 


\section{Hipotesis Ketiga}

Hipotesis ketiga yang diuji dalam penelitian ini adalah bahwa kesegaran jasmani dan motivasi belajar siswa bersama-sama berhubungan dengan hasil belajar siswa. Untuk menguji hipotesis ini terlebih dahulu dilakukan analisis korelasi ganda. Hasil analisis korelasi kesegaran jasmani dan motivasi belajar siswa secara bersama-sama dengan hasil belajar siswa dapat dilihat pada rangkuman hasil korelasi ganda pada Tabel 7.

Tabel 7 Rangkuman Hasil Analisis Korelasi Kesegaran jasmani $\left(X_{1}\right)$ dan motivasi belajar siswa $\left(\mathbf{X}_{2}\right)$ dengan Hasil Belajar Siswa (Y)

\begin{tabular}{|c|c|c|}
\hline Korelasi & Koefisien Korelasi $(\mathrm{R})$ & Koefisien Determinasi $\left(\mathrm{R}^{2}\right)$ \\
\hline (ryl2) & 0,661 & 0,436 \\
\hline
\end{tabular}

Hasil perhitungan pada Tabel 17 menunjukkan bahwa harga koefisien korelasi ganda kesegaran jasmani dan motivasi belajar siswa secara bersama-sama berhubungan dengan hasil belajar siswa $\left(\mathrm{R}_{\mathrm{y}} 12\right)$ adalah sebesar $R$ hitung 0,661 dengan $R$ tabel 0,396 dan koefisien determinasi $\left(R^{2}{ }_{y 12}\right)$ sebesar 0,436 . Ini berarti bahwa kesegaran jasmani dan motivasi belajar siswa secara bersama-sama mempunyai berkorelasi secara sangat signifikan dengan hasil belajar siswa.

Untuk mengetahui bentuk hubungan kesegaran jasmani $\left(\mathrm{X}_{1}\right)$ dan motivasi belajar siswa $\left(\mathrm{X}_{2}\right)$ secara bersama dengan hasil belajar siswa (Y), dilakukan analisis regresi ganda. Hasil analisis diperoleh persamaan regresi $\hat{\mathbf{Y}}=\mathbf{5 6}, \mathbf{5 3}+\mathbf{1}, \mathbf{7 8 2} \mathbf{X}_{\mathbf{1}}+\mathbf{0 , 0 3 8} \mathbf{X}_{2}$. Persamaan ini kemudian diuji keberartian dengan uji $\mathrm{F}$. Rangkuman hasil pengujian keberartian persamaan dapat dilihat pada Tabel 24

Hasil perhitungan dengan harga $\mathrm{F}_{\text {hitung }}$ sebesar 11,73 dengan nilai $p=0,000<\alpha=0,01$. Ini berarti bahwa persamaan regresi $\hat{\mathbf{Y}}=\mathbf{5 6 , 5 3}+\mathbf{1 , 7 8 2}_{1}+\mathbf{0 , 0 3 8 X _ { 2 }}$ adalah sangat signifikan. Selanjutnya dilakukan uji keberartian koefisien regresi. Rangkuman hasil analisis dapat dilihat pada Tabel 8.

Tabel 8 Uji Keberartian Koefisien $X_{1}$ dan $X_{2}$ terhadap $Y$

\begin{tabular}{|l|c|c|c|}
\hline \multicolumn{1}{|c|}{ Sumber } & Koefisien & $\mathrm{t}$ & Sig. \\
\hline Konstanta & 56,53 & 5.812 & 0.000 \\
\hline Kesegaran jasmani & 1.782 & 4.131 & 0.001 \\
\hline Motivasi belajar & 0.038 & 2.050 & 0.027 \\
\hline
\end{tabular}

Pada Tabel 8 kelihatan bahwa harga t koefisien regresi kesegaran jasmani 1,782 dan taraf signifikan 0,001 dan harga $t$ koefisien regresi motivasi belajar siswa 0,2,050 dengan taraf signifikan 0,0002. Ini berarti bahwa koefisien regresi kesegaran jasmani $=1,782$ dan koefisien regresi motivasi belajar $=0,038$ sangat signifikan dan dapat digunakan untuk memprediksi hasil belajar siswa. Model regresi di atas menjelaskan bahwa setiap peningkatan kesegaran jasmani 1 skala dan motivasi belajar 1 skala akan berhubungan dengan hasil belajar skala, dan skala hasil belajar sudah ada sebesar 56,528. Kenaikan variabel kesegaran jasmani dan motivasi belajar siswa putra secara bersama-sama akan mempengaruhi variabel hasil belajar (Y).

Berdasarkan hasil pengujian yang semuanya sangat signifikan maka hipotesis yang menyatakan bahwa " kesegaran jasmani dan motivasi belajar siswa putra secara bersama-sama berhubungan dengan hasil belajar siswa dapat diterima dalam taraf kepercayaan $95 \%$ dan besar hubungan sebesar 43,7\%.

Berdasarkan hasil analisis dan pengujian hipotesis, menunjukkan bahwa ketiga hipotesis yang diajukan dapat diterima. Dengan demikian diyakini bahwa variabel bebas yaitu kesegaran jasmani siswa dan motivasi belajar siswa berhubungan dengan hasil belajar siswa, baik secara sendiri-sendiri maupun secara bersamasama.

Penelitian ini menunjukkan besar hubungan kesegaran jasmani tersebut berhubungan dengan hasil belajar siswa putra karena $r$ hitung $>r$ tabel sebesar 0,654>0,396, motivasi belajar siswa berhubungan dengan hasil belajar siswa karena $r$ hitung $>r$ tabel $(0,453>0,396)$, Kesegaran jasmani Siswa dan motivasi belajar siswa secara bersama-sama berhungan dengan hasil belajar siswa karena $R$ hitung $>\mathrm{R}$ tabel $(0,718>0,396)$ Hasil penelitian ini menunjukkan bahwa kesegaran jasmani memiliki hubungan yang signifikan dan memberikan berhubungan yang berarti untuk hasil belajar siswa sebesar 51,5\%, hal ini menunjukkan bahwa Kesegaran jasmani memegang peranan penting dalam meningkatkan hasil belajar siswa.

Penelitian ini mengungkapkan bahwa selain motivasi belajar siswa juga berhubungan dengan hasil belajar siswa. Guru merupakan faktor yang paling berhubungan dengan proses dan hasil belajar. 
Penelitian ini menunjukkan besar hubungan kesegaran jasmani siswa putri tersebut berhubungan dengan hasil belajar siswa putra karena $r$ hitung $>r$ tabel sebesar 0,488>0,413, motivasi belajar siswa berhubungan dengan hasil belajar siswa putri karena $r$ hitung $>r$ tabel $(0,420>0,413)$, Kesegaran jasmani Siswa dan motivasi belajar siswa secara bersama-sama berhungan dengan hasil belajar siswa karena $\mathrm{R}$ hitung $>\mathrm{R}$ tabel $(0,877>0,413)$

Hasil penelitian ini menunjukkan bahwa kesegaran jasmani memiliki hubungan yang signifikan dan memberikan berhubungan yang berarti untuk hasil belajar siswa sebesar 76,9\%, hal ini menunjukkan bahwa Kesegaran jasmani memegang peranan penting dalam meningkatkan hasil belajar siswa.

Penelitian ini mengungkapkan bahwa selain motivasi belajar siswa juga berhubungan dengan hasil belajar siswa. Guru merupakan faktor yang paling berhubungan dengan proses dan hasil belajar.

Hasil penelitian ini menunjukkan bahwa kesegaran jasmani siswa dan motivasi belajar siswa secara bersama-sama berhubungan dengan hasil belajar baik siswa putra maupun siswa putri apabila siswa mempunyai kesegaran jasmani dan motivasi yang kuat dalam belajar maka hasil belajar siswa akan baik. Ternyata dalam hasil penelitaian ini, secara umum siswa SDN 12 Pulau Punjung mempunyai motivasi yang sedang (cukup), begitu juga kesegaran jasmani siswa juga berada pada kategori cukup, sehingga hasil belajar siswa juga berada pada kategori sedang. Peneliti menyimpulkan bahawa hasil belajar siswa berhubungan dengan kesegaran jasmani dan motivasi belajar siswa berhubungan dengan hasil belajar siswa.

\section{SIMPULAN}

Berdasarkan hasil penelitian dan pembahasan maka dapat disimpulkan bahwa Kesegaran jasmani berhubungan dengan hasil belajar siswa putra SDN 12 Pulau Punjung karena $r$ hitung $>\mathrm{r}$ tabel sebesar $0,654>0,396$

\section{DAFTAR PUSTAKA}

Anita, Lie. dkk.2007. Strategi Pembelajaran di SD. Jakarta: Universitas Terbuka Arikunto, Suharsimi. 2008. Dasar-Dasar Evaluasi Pendidikan. Jakarta: Bumi. Aksara

Dakhi, O. "Aplikasi Pendeteksian Kerusakan File Akibat Virus Dengan Menggunakan Metode Heuristic." Pelita Informatika Budi Darma, vol. 4, no. 1, pp. 35-41, 2013.

Dakhi, O. 2013. Belajar Javascript Dengan Mudah Dan Detail. Jakarta: Dapur Buku. pp. 1-202.

Dalyono. 2007. Psikologi Pendidikan. Jakarta : Rineka Cipta.

Dangsina Moeloek dan Arjatmo Tjokronegoro. 1984. Kesehatan Olahraga. Jakarta:F UI Dimyati dan Midjiono. 2002. Belajar dan Pembelajaran. Jakarta: Dirjen Dikti

Engkos Kosasih. 1983. Olaharaga dan Kesehatan. Jakarta: Erlangga

Pusat Kesegaran Jasmani. 1999. Tes Kesegaran Jasmani Indonesia (TKJI). Jakarta: Gn Mulia

Pusat Kesegaran Jasmani dan Rekreasi. 1999. Ketahuilah Kesegaran Jasmani Anda. Jakarta. http://www.kesegaran jasmani.com

Sarumaha, R., Harefa, D., \& Zagoto, Maria M. (2018). Upaya Meningkatkan Kemampuan Pemahaman Konsep Geometri Transformasi Refleksi Siswa Kelas XII-IPA-B SMA Kampus Telukdalam Melalui Model Pembelajaran Discovery Learning Berbantuan Media Kertas Milimeter. Jurnal Education and development, Vol.6 No.1, 90-96. https://doi.org/10.37081/ed.v6i1.668

Sardiman A.M. .2010. Interaksi dan Motivasi Belajar Mengajar. Jakarta: PT. Raja Grafindo Slameto. 2010. Belajar dan Faktor-faktor Yang Mempengaruhinya. Jakarta: Rineka Cipta Sudjana. 2002, Metoda Statistika. Bandung: Penerbit Tarsito.

Sumadi Suryabrata.1991. Psikologi Pendidikan. Jakarta: CV Rajawali Grafika Persada

Wiranto Arismunandar. 1997. Makalah: Masa Depan Penjas dan Olahraga Di Indonesia. Bandung: IKA IKIP Bandung.

Zagoto, Maria M., Yarni, Nevi; Dakhi, O. (2019). Perbedaan Individu dari Gaya Belajarnya Serta Implikasinya Dalam Pembelajaran. Jurnal Review Pendidikan dan Pengajaran, 2(2), 259-265.

Zagoto, Maria M. \& Dakhi, O (2018). Pengembangan Perangkat Pembelajaran Matematika Peminatan Berbasis Pendekatan Saintifik Untuk Siswa Kelas XI Sekolah Menengah Atas. Jurnal Review Pendidikan dan Pengajaran, 1(1), 157-170.

Zagoto, Maria M. (2018). Pengembangan Perangkat Pembelajaran Matematika Berbasis Realistic Mathematic Educations Untuk Siswa Kelas V Sekolah Dasar, Jurnal Education And Development, vol. 3, no. 1, p. 53, Feb. 2018. https://doi.org/10.37081/ed.v3i1.139

Zainul, Asnawi dan Mulyasa Agus. 2003. Tes dan Asesmen di SD. Jakarta: Universitas Terbuka 